\title{
Beef production as influenced by stage of maturity of grass for silage and level and type of supplementary concentrates
}

\author{
Ilmo Aronen, Vesa Toivonen, Elise Ketoja and JukKa Öfversten
}

\begin{abstract}
Aronen, I., Toivonen, V., Ketoja, E. \& Öfversten, J. 1992. Beef production as influenced by stage of maturity of grass for silage and level and type of supplementary concentrates. Agric. Sci. Finl. 1: 441-460. (Agric. Res. Centre of Finland, Inst. Animal Production, SF-31600 Jokioinen, Finland and Agric. Res. Centre of Finland, Data and Information Services, SF-31600 Jokioinen, Finland.)
\end{abstract}

The aim of this study was to examine the effects of stage of maturity of grass for silage (EC = early cut, $\mathrm{LC}=$ late cut), and level ( $\mathrm{LL}=$ low level, i.e., $1.5 \mathrm{~kg}$ dry matter (DM) $\mathrm{d}^{-1}, \mathrm{HL}=$ high level, i.e., $\left.3.0 \mathrm{~kg} \mathrm{DM} \mathrm{d}^{-1}\right)$ and type $(\mathrm{B}=$ barley, $\mathrm{BRSM}=$ barley and heatmoisture treated rapeseed meal) of supplementary concentrates on feed intake, animal performance and diet digestion in Finnish Ayrshire bulls. The study was conducted as a $2^{3}$ factorial experiment with six randomized complete blocks.

The average initial and final live weights of the bulls were $123 \mathrm{~kg}$ and $494 \mathrm{~kg}$, respectively. The crude protein content of the ad libitum fed EC and LC silages, cut at an interval of eight days, was 159 and $131 \mathrm{~g} \mathrm{~kg}^{-1} \mathrm{DM}$. However, the difference in the estimated content of AAT ( $=$ amino acids absorbed in the small intestine) between the two silages was small, whereas there was a large difference in PBV (= protein balance in the rumen). The respective values for crude fibre were 278 and $304 \mathrm{~g} \mathrm{~kg}^{-1} \mathrm{DM}$.

At the beginning of the experiment the voluntary grass silage intake of the EC bulls was higher than that of the LC bulls. Towards the end of the experiment the difference in silage intake between the two stages of cut disappeared. This change in voluntary grass silage intake was followed by a similar change in the rate of daily live weight gain (LWG): the EC bulls started to grow faster than the LC bulls, but the initial slower LWG of the LC bulls had been compensated by the end of the experiment.

The LL bulls had a higher intake of silage than the HL bulls. The substitution rate was $0.63 \mathrm{~kg}$ silage DM per concentrate DM, regardless of the stage of cut. HL feeding resulted in faster LWG.

Owing, at least partly, to the improved diet digestibility, inclusion of rapeseed meal in the diet increased the silage intake throughout the experiment followed by a faster LWG. The positive effect of rapeseed meal was unaffected by the stage of maturity of the grass for silage and the level of concentrate supply.

The animals were not able to take full advantage of the high protein content of the EC silage. The inclusion of rapeseed meal in the diet, however, improved the rate of gain and resulted in more efficient feed conversion.

Key words: rapeseed meal, protein evaluation, diet digestion, feed intake, substitution rate, live weight gain

\section{Introduction}

Livestock production in Finland is largely based on grass silage feeding. Grass is usually cut at an early stage of maturity to obtain silage of high digestibility and high protein content. On the other hand, a delayed cutting will increase the dry matter (DM) yield ha-1. 
In an intensive beef production system, grass silage is always supplemented with concentrates to increase the total nutrients intake and thereby the rate of daily live weight gain (LWG). The supplementary concentrates are mainly based on barley grain. Rapeseed meal (RSM) is commonly used as an ingredient in protein concentrates.

Inclusion of concentrates in the diet usually decreases the voluntary grass silage intake (ETTALA and LAMPILA 1978, STEEN 1984). Nevertheless, in many experiments protein supplementation has been found to increase roughage intake (e.g., CODY et al. 1990, DonaldSon et al. 1991). It has been suggested that the stimulating effect involves a cycle of improved efficiency of microbial protein synthesis, increased DM digestibility and thereby increased feed intake (NOCEK and RUSSELl 1988). However, in experiments with grass silage, results have been somewhat contradictory. HUHTANEN et al. (1985), Steen (1988), Aronen (1990) and MolONEY (1991) did not find any change in voluntary grass silage intake when protein supplements were included in the diet, while ARONEN (1991) and Aronen and Vanhatalo (1992) recorded an increased grass silage intake with a resultant enhancement in LWG of bulls.

The aim of this experiment was to study the voluntary grass silage intake and LWG of Ayrshire bulls in relation to the stage of maturity of grass for silage supplemented with two different levels and types of concentrates. Special attention was paid to possible interactions between the stage of maturity of grass for silage and the type of the supplementary concentrates (i.e., barley or barley together with RSM) to find out whether the effect of RSM depends on the protein and energy content of the grass silage. Similarly, the interaction between the protein supplementation and the level of concentrate in the diet was of interest, because earlier findings by WATERHOUSE et al. (1983) suggested that lower responses to protein supplementation were to be expected for diets with a high concentrate level.

In some experiments (HAKKOLA 1985, JOKIToKola 1991, Aronen and Vanhatalo 1992), the positive effect of protein supplementation on LWG was sustained throughout the experiment, while in others (HuHTANEN et al. 1989, Aronen 1990) the positive effect of RSM on LWG was restricted to the early phase of the growth period (i.e., live weight below $300 \mathrm{~kg}$ ). Therefore, the manner in which the treatment effects and their possible interactions change with the phase of the production experiment was examined in the present study. Furthermore, the apparent digestibility of the diets was determined at the end of the production experiment in order to find out the relationship between diet digestion and feed intake.

\section{Material and methods}

\section{Animals and their feeding}

Six blocks of eight Finnish Ayrshire bull calves were formed on the basis of live weight (LW). The calves within the blocks were then randomly allotted to $2^{3}$ factorial treatment combinations. The three factors were: stage of maturity of grass for silage $(\mathrm{EC}=$ early cut, $\mathrm{LC}=$ late cut $)$, level of concentrates $\left(\mathrm{LL}=\right.$ low level, i.e., $1.5 \mathrm{~kg} \mathrm{DM} \mathrm{d}^{-1}, \mathrm{HL}=$ high level, i.e., $3.0 \mathrm{~kg} \mathrm{DM} \mathrm{d}^{-1}$ ) and type of concentrates ( $\mathrm{B}=$ barley, BRSM = barley and RSM). For BRSM diets, $1.5 \mathrm{~kg}$ of barley was replaced by a mixture of barley and RSM (66:34) to provide $0.5 \mathrm{~kg}$ of RSM $\mathrm{d}^{-1}$. The average initial live weight of the bulls was $123 \mathrm{~kg}$. Three of the animals were lost during the experiment for reasons not related to the treatments.

Direct cut grass from a cocksfoot-timothy (Dactylis glomerata - Phleum pratense) sward was ensiled in bunker silos with a formic acid-based additive (AIV II; $80 \%(\mathrm{w} / \mathrm{w}$ ) formic acid, $2 \%$ orthophosphoric acid) applied at the rate of $51 \mathrm{t}^{-1}$. The silages were fed ad libitum. The EC silages (two silos) were harvested on 5-7 June 1989 (at the beginning of the ear emergence stage of timothy) and on 2-3 August 1990 (one silo), and the LC silages on 14-15 June 1989 (two silos) and on 8-10 August 1990 (one silo). The silages in 1989 were of the first cut and in 1990 of the second cut. N, P and $\mathrm{K}$ fertilization per ha was $110 \mathrm{~kg}, 22 \mathrm{~kg}$ and $44 \mathrm{~kg}$ 
for the first cut and $93 \mathrm{~kg}, 19 \mathrm{~kg}$ and $37 \mathrm{~kg}$ for the second cut, respectively.

The daily allowance of concentrates was gradually increased from $1.5 \mathrm{~kg}$ to $2.0 \mathrm{~kg}$ for the LL bulls and from $1.5 \mathrm{~kg}$ to $5.5 \mathrm{~kg}$ for the HL bulls. The RSM was heat-moisture treated (ÖPEX ${ }^{\otimes}$. TuLISALO 1990).

\section{Experimental procedure and analytical methods}

The experiment was started when the animals had reached an average age of 17 weeks and it lasted for 12 four-week periods. The animals were weighed at the start of the experiment and on the last day of each 28-day period. LWG for each 28-day period was calculated by difference. At the end of the experiment the animals were slaughtered. A description of the slaughter technique is given by Aronen (1990).

The individual feed intake was measured daily. The pelleted concentrates were fed twice daily and grass silage once daily. Feed samples were taken at every feeding and pooled for periods of two weeks for grass silage and four weeks for concentrates. Proximate feed analyses were carried out conventionally. The correction for volatile losses in grass silage was made according to HUIDA et al. (1986). Fermentation quality of the grass silages was analyzed as described by VANHATALO et al. (1992).

Apparent in vivo digestibility of the silages in the six bunker silos was determined in four wethers. Table values (SALO et al. 1990) were applied for the digestibility of barley and the values determined in wethers (VANHATALO et al. unpubl.) were applied for RSM. The digestibility coefficients were used to calculate metabolizable energy (ME) and net energy (NE). ME values were calculated according to MAFF (1975) and the values for NE (in feed units, FU) according to SALO et al. (1990).

In order to evaluate protein feeding according to the AAT-PBV system (HvElPLUND and MADSEN 1990), the protein intake was calculated in terms of AAT (amino acids absorbed in the small intestine) and PBV (protein balance in the rumen). The rate of disappearance of feed $\mathrm{N}$ from nylon bags was determined for each feed (six silages and two concentrates) in three adult non-lactating Finnish Ayrshire cows equipped with a rumen cannula and a duodenal t-shaped cannula and fed at maintenance with grass silage and barley (70:30 on a DM basis). A description of the incubation techniques for concentrates is given by ARONEN (1991) and for grass silages by VANHATALO et al. (1992).

Degradability of crude protein (DEG) was calculated according to ØRSKOV and MCDONALD (1979) using a rumen outflow rate $(\mathrm{k})$ of $8 \% \mathrm{~h}^{-1}$ for concentrates and $3 \% \mathrm{~h}^{-1}$ for silages. A correction for microbial contamination in grass silage samples was made according to MichaleT-DOREAU and OULD-BAH (1989), and a correction for small particle losses from the bags in concentrates according to WeIsBJERG et al. (1990).

True digestibility of undegraded feed protein in the intestine was calculated according to HVELPLUND et al. (1991). For this purpose the intestinal degradation of intact feeds was measured by the mobile bag method using freeze-dried grass silage and air-dry concentrates. A description of the method is given by VanHatalo et al. (1992).

During the last four-week period of the feeding experiment, when the animals had reached an average live weight of $473 \mathrm{~kg}$, the apparent in vivo digestibility of the diets was determined. Acid-insoluble ash (AIA) was used as a natural marker (VAN KEULEN and YoUNG 1977). Arrangement of the treatments during the digestibility trial was similar to that in the feeding experiment, except that the animals on LL feeding received $2.5 \mathrm{~kg} \mathrm{~d}^{-1}$ of concentrates and those on $\mathrm{HL}$ feeding $5.0 \mathrm{~kg} \mathrm{~d}^{-1}$. The silages were of second cut and were fed at the level of $90 \%$ of the ad libitum intake. Feed samples were taken at every feeding and pooled for the experimental period of five days. Faecal grab samples were taken when feeding the animals at $07.15 \mathrm{hrs}$ and at $15.30 \mathrm{hrs}$. In addition to proximate feed analyses, faecal and feed samples were analyzed for AIA using $4 \mathrm{~N}$ acid according to VAN KeUlen and Young (1977). Due to palatability problems, one of the 45 bulls was excluded from the calculations. 


\section{Statistical methods}

For each bull, LWG and intake of nutrients was first calculated for 12 consecutive periods. It was found that two adjacent measurements could be combined without loss of any relevant information. Consequently, six repeated measurements (Period 1 to Period 6) of the same variables were recorded for each experimental unit (bull).

Typically, the measurements of an experimental unit over time are dependent on each other and a proper analysis of the measurement data must take into account these dependences. In the present study, a multivariate analysis of variance approach was used, which assumes no knowledge of the dependence structure (covariance structure) of the repeated measurements. This approach is presented, e.g., by Crowder and HAND (1990).

In the multivariate approach, the effects of the treatments on all response variables, in this case on all six repeated measures of the same experimental unit, are observed simultaneously. This gives a vector response, and not just one (scalar) response as is the case in the separate univariate (one variable at a time) analysis. Let $(i, j, k)$ identify the combination of different factor levels (e.g., $i=$ early stage of cut, $j=$ low level of concentrates; $k=$ barley). Further, let the response vector for the bull assigned to the $(i, j, k)$ th treatment combination in the $l$ th block be the following (written as a row vector):

$\mathrm{y}_{i j k l}^{\prime}=\left[\mathrm{y}_{i j k l l}, \mathrm{y}_{\mathrm{ijk} \mid 2,}, \mathrm{y}_{i j k l 3}, \mathrm{y}_{\mathrm{ijk} \mid 4}, \mathrm{y}_{\mathrm{ijk} \mid 5}, \mathrm{y}_{\mathrm{ijk} \mid 6}\right]$

The model used for $\mathrm{y}_{i j k l}$, had the form $\mathbf{y}_{i j k l}^{\prime}=\mu+\alpha_{i}+\boldsymbol{B}_{\mathrm{j}}+\gamma_{\mathrm{k}}+(\alpha \mathbf{B})_{i j}+(\alpha \gamma)_{i k}+(\mathbf{B} \gamma)_{j k}+$ $(\alpha \mathbf{B} \gamma)_{i j k}+\delta_{l}+\varepsilon_{\mathrm{ijk} \mathrm{l}}$,

where, like the response, all the parameters are $6 \times 1$ vectors, and $\mu$ is the vector of period means, $\alpha$ is the effect of stage of cut, $\mathbf{B}$ is the effect of level of concentrate, $\gamma$ is the effect of type of concentrate, $\alpha \mathbf{B}, \alpha \gamma, \mathbf{B} \gamma$ and $\alpha \mathbf{B} \gamma$ are the corresponding interactions, $\delta$ is the block effect and $\varepsilon$ is the vector of random errors. The components of the vector $\varepsilon$ are assumed to have a joint multivariate normal distribution with mean vector $\mathbf{0}$ and arbitrary covariance matrix $\Sigma$ (i.e., the model does not include any assumptions concerning the covariance structure of the repeated measurements).

In a multivariate analysis of variance, the testing of hypotheses is based on a comparison of matrices (instead of sums of squares). There is, however, no one single correct way of comparing matrices, and various alternative test statistics have been proposed for hypothesis testing. The SAS GLM procedure (SAS 1990), by which the analyses were performed in this study, includes the four most common test statistics, namely Wilks' Lambda, Roy's Largest Root, Hotelling-Lawley Trace and Pillai's Trace. All of these tests gave similar results in our study, although this is not always the case.

In the digestibility trial, conducted with growing cattle at the end of the production experiment, the digestibility variables (crude protein, ether extract, crude fibre and nitrogen-free extracts) were highly correlated. This data resembled the repeated measures data above in that there were several correlated measurements recorded for each bull. However, now the measurements included four different variables. Nevertheless, the statistical model on which the analysis was based, was analogous to the one given above. The digestibility of organic matter was studied by using the corresponding univariate model.

When interpreting the diet digestibility data, the results of the multivariate tests were examined first. Only if these results were significant, the results of the corresponding univariate analyses were then examined to locate those digestibility variables which seemed to contribute most to the results of the multivariate tests. However, the univariate analyses do not take into account the correlations between the response variables and, therefore, when there are correlations, their results should be interpreted with caution.

\section{Results}

\section{Chemical composition and feed value of the feeds}

The first-cut silages (harvested in 1989) were fed 
during Periods 1 to 4 and the second-cut silages (harvested in 1990) during Periods 5 and 6. The fermentation quality of both silages was good (Table 1). No butyric acid was observed. During the first four periods the proportion of $\mathrm{NH}_{3}-\mathrm{N}$ and soluble $\mathrm{N}$ of total $\mathrm{N}$ was greater in the LC silage than in the EC silage, the opposite being true during the last two periods.

In relation to the time interval between the har-

Table 1. Fermentation quality of the grass silages in the feeding experiment.

Early cut Late cut

Periods $1+2$

$\mathrm{pH}$

In dry matter (DM), $\mathrm{g} \mathrm{kg}^{-1}$

Lactic acid

Acetic acid

Propionic acid

Sugars

Ethanol

In total nitrogen $(\mathrm{N}), \mathrm{g} \mathrm{kg}^{-1}$

$\mathrm{NH}_{3}-\mathrm{N}$

Soluble N

Periods $3+4$

$\mathrm{pH}$

In DM, $\mathrm{g} \mathrm{kg}^{-1}$

Lactic acid

Acetic acid

Propionic acid

Sugars

Ethanol

In total $\mathrm{N}, \mathrm{g} \mathrm{kg}^{-1}$

$\mathrm{NH}_{3}-\mathrm{N}$

Soluble N

Periods $5+6$

$\mathrm{pH}$

In DM, $\mathrm{g} \mathrm{kg}^{-1}$

Lactic acid

Acetic acid

Propionic acid

Sugars

Ethanol

In total $\mathrm{N}, \mathrm{g} \mathrm{kg}^{-1}$

$\mathrm{NH}_{3}-\mathrm{N}$

Soluble N

$4.1^{\circ} \quad 4.1^{\circ}$

$42 \quad 42$

18

0

32

8

46

476

4.0

4.1

48

16

0

28

10

44

541

59

613

56
520

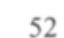

17

0

32

9

59

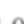

4.0

4.1

71

15

0

36

6

46

505 vesting of the EC and LC silages, the crude protein (CP) content decreased by $0.39 \%$-units per day and the crude fibre (CF) content increased by $0.35 \%$ units per day for the silages of the first cut. For the second-cut silages the rate of change was slower. The decrease in CP content and the increase in CF content were 0.29 and $0.25 \%$-units, respectively (Table 2).

The digestible crude protein (DCP) content was higher in the EC silage than in the LC silage (Table 3 ). When the protein value of the silages was given in terms of AAT the difference was much smaller. However, PBV in the EC silage was substantially larger than PBV in the LC silage.

Table 2. Average chemical composition ( $\mathrm{g} \mathrm{kg}^{-1}$ dry matter) of the experimental feeds.

$\begin{array}{lll}\text { Grass silage } & \begin{array}{r}\text { Barley } \\ \text { Mixture of } \\ \text { barley and } \\ \text { RSM }^{1)}\end{array} \\ \begin{array}{lll}\text { Early } & \text { Late } \\ \text { cut } & \text { cut }\end{array} & \end{array}$

Periods $1+2$

Dry matter (DM), $\mathrm{g} \mathrm{kg}^{-1} 223$

Ash

68

$235 \quad 873$

874

Crude protein (CP) 160

$74 \quad 28$

40

Ether extract (EE) 50

$127 \quad 157$

223

39

157
26

38

Crude fibre (CF)

279

312

42

68

$\mathrm{N}$ free extracts (NFE) 444

$449 \quad 747$

630

Periods $3+4$

$\begin{array}{lrrrr}\text { DM, g kg }{ }^{-1} & 233 & 252 & 880 & 881 \\ \text { Ash } & 68 & 72 & 25 & 41 \\ \text { CP } & 160 & 126 & 139 & 218 \\ \text { EE } & 55 & 43 & 24 & 38 \\ \text { CF } & 281 & 307 & 42 & 70 \\ \text { NFE } & 437 & 453 & 770 & 633\end{array}$

Periods $5+6$

$\begin{array}{lrrrr}\text { DM, g kg-1 } & 239 & 230 & 877 & 874 \\ \text { Ash } & 91 & 89 & 28 & 43 \\ \text { CP } & 158 & 139 & 150 & 224 \\ \text { EE } & 52 & 43 & 25 & 34 \\ \text { CF } & 281 & 297 & 43 & 71 \\ \text { NFE } & 418 & 431 & 755 & 629\end{array}$

${ }^{1)}$ Mixture of barley and rapeseed meal (66:34). 
Table 3. Feed values (per kg dry matter) and degradability of crude protein (DEG) of the experimental feeds.

\begin{tabular}{llll}
\hline Grass silage & Barley & $\begin{array}{l}\text { Mixture of } \\
\text { barley and } \\
\text { RSM }^{1)}\end{array}$ \\
\cline { 2 - 3 } & $\begin{array}{l}\text { Early } \\
\text { cut }\end{array}$ cate & & \\
\hline
\end{tabular}

\section{Periods $1+2$}

$\begin{array}{lrrrr}\text { NE, FU } & 0.83 & 0.79 & 1.14 & 1.09 \\ \text { ME, MJ } & 11.8 & 11.2 & 13.3 & 13.0 \\ \text { DCP, g } & 123 & 89 & 114 & 179 \\ \text { AAT, g } & 65 & 62 & 104 & 126 \\ \text { PBV, g } & 43 & 15 & -10 & 26 \\ \text { DEG, \% } & 91 & 92 & 72 & 58\end{array}$

Periods $3+4$

$\begin{array}{lrrrr}\text { NE, FU } & 0.83 & 0.79 & 1.15 & 1.09 \\ \text { ME, MJ } & 11.6 & 11.1 & 13.4 & 13.0 \\ \text { DCP, g } & 119 & 86 & 102 & 174 \\ \text { AAT, g } & 64 & 62 & 103 & 125 \\ \text { PBV, g } & 45 & 12 & -26 & 22 \\ \text { DEG, \% } & 91 & 91 & 72 & 58\end{array}$

Periods $5+6$

$\begin{array}{lrrrr}\text { NE, FU } & 0.77 & 0.75 & 1.14 & 1.09 \\ \text { ME, MJ } & 10.9 & 10.6 & 13.3 & 12.9 \\ \text { DCP, g } & 114 & 95 & 109 & 179 \\ \text { AAT, g } & 59 & 60 & 103 & 126 \\ \text { PBV, g } & 50 & 27 & -16 & 26 \\ \text { DEG, \% } & 91 & 88 & 72 & 58\end{array}$

\section{1) Mixture of barley and rapeseed meal (66:34).}

NE, net energy; ME, metabolizable energy; FU, feed units; DCP, digestible crude protein; AAT, amino acids absorbed in the small intestine; PBV, protein balance in the rumen; DEG, degradability of crude protein.

\section{Feed intake}

The palatability of the concentrates was good and only occasional refusals were recorded. There was no marked difference in concentrate intake between the EC and LC feeding groups (Figure 1). Neither was there any difference in concentrate intake between the two types of concentrates, B and BRSM. However, the daily concentrate intake of the HL bulls was, as intended, almost twice as high as that of the LL bulls.

The larger grass silage intake of the EC bulls compared to the LC bulls was apparent at the beginning of the experiment (Table 4, Figure 1a). However, the difference had vanished by the end of the experiment. This interaction between the stage of maturity of grass for silage and the period was significant $(\mathrm{p}<0.005)$.

The LL bulls had a higher silage intake than the HL bulls (Table 4, Figure 1b). As intended, the change with time in concentrate supply during the feeding experiment was steeper in $\mathrm{HL}$ feeding than in LL feeding, which resulted in an interaction in silage intake between the level of concentrate and the period $(\mathrm{p}<0.001)$.

Inclusion of RSM in the diet tended $(p=0.07)$ to increase the grass silage intake throughout the experiment (Table 4, Figure 1c) but no significant interaction in silage intake between the type of concentrate and the period was observed.

\section{Protein and energy supply}

AAT intake, given in $\mathrm{AAT}_{f}(=\mathrm{AAT}$ of feed origin), $\mathrm{AAT}_{\mathrm{m}}$ (=AAT of microbial origin) and AAT $\left(=\mathrm{AAT}_{\mathrm{f}}+\mathrm{AAT}_{\mathrm{m}}\right.$, total amount of amino acids absorbed in the small intestine), calculated for the entire experimental period, is given in Table 5. In general, the proportion of $\mathrm{AAT}_{f}$ of total AAT was small. It varied between $13.2 \%$ (late-cut silage supplemented with low level of barley) and $25.6 \%$ (late-cut silage supplemented with high level of barley together with RSM).

Analogously to the changes in DM intake, the difference in AAT intake between EC and LC feeding had disappeared $(\mathrm{p}<0.005$ for stage of cut * period interaction) by the end of the experiment (Table 6). The difference in AAT intake between LL and HL feeding increased $(\mathrm{p}<0.001$ for level of concentrate $*$ period interaction) towards the end of the experiment, but the difference $(p<0.001$ for type of concentrate main effect) in AAT intake between B and BRSM feeding, originating from $\mathrm{AAT}_{f}$, was stable throughout the experiment.

The large difference in PBV between EC and LC 
a

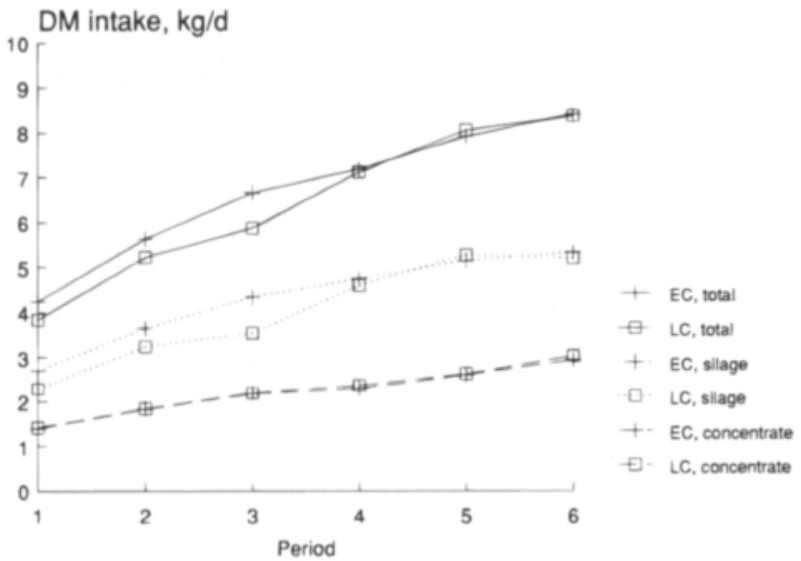

b

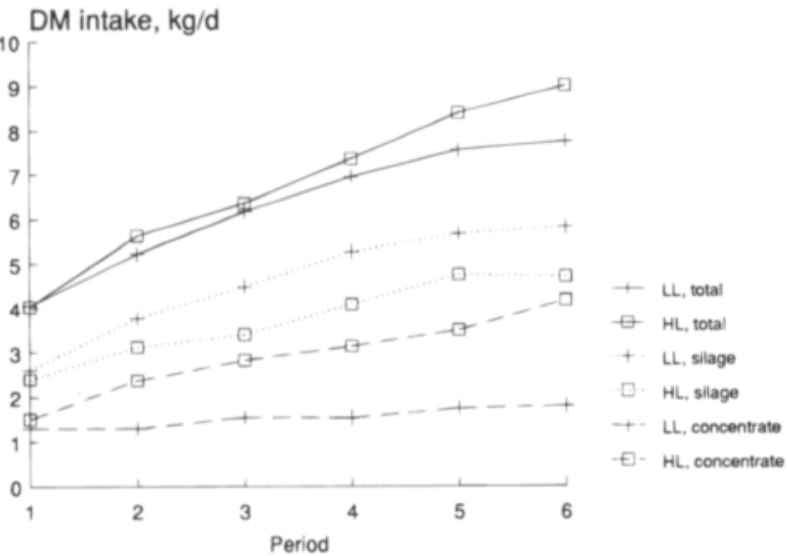

c

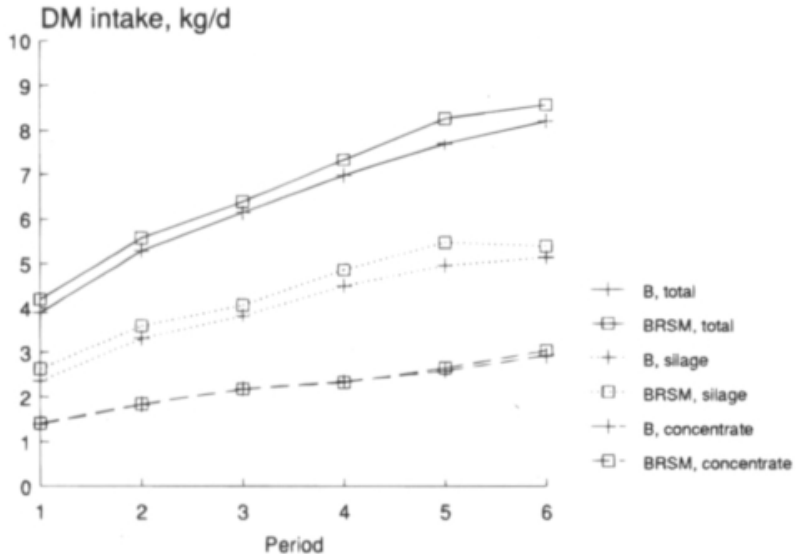

Fig. 1. Mean profiles illustrating the effects of stage of maturity of grass for silage (a) and level (b) and type (c) of concentrates on the feed dry matter (DM) intake of Ayrshire bulls. EC, early-cut silage; LC, late-cut silage; LL, low level of concentrates; HL, high level of concentrates; B, barley; BRSM, barley and rapeseed 
Table 4. Feed intake $\left(\mathrm{kg} \mathrm{DM} \mathrm{d}^{-1}\right)$ during the production experiment. Comparison of stage of maturity of grass for silage, level of concentrate and type of concentrate least squares means for each period and during the whole experiment.

\begin{tabular}{|c|c|c|c|c|c|c|c|c|c|}
\hline \multicolumn{10}{|c|}{ Period } \\
\hline & & $\mathrm{n}$ & 1 & 2 & 3 & 4 & 5 & 6 & Mean \\
\hline \multicolumn{10}{|c|}{ Total DM } \\
\hline \multicolumn{10}{|c|}{ Stage of cut } \\
\hline Early & (E) & 22 & 4.24 & 5.63 & 6.66 & 7.19 & 7.91 & 8.41 & 6.67 \\
\hline \multirow[t]{2}{*}{ Late } & (L) & 23 & 3.84 & 5.22 & 5.87 & 7.12 & 8.05 & 8.37 & 6.41 \\
\hline & E-L & & 0.40 & 0.41 & 0.79 & 0.07 & -0.14 & 0.04 & 0.26 \\
\hline \multicolumn{10}{|c|}{$\begin{array}{l}\text { Level of } \\
\text { concentrate }\end{array}$} \\
\hline Low & $(\mathrm{LL})$ & 23 & 4.05 & 5.22 & 6.17 & 6.95 & 7.56 & 7.76 & 6.29 \\
\hline \multirow[t]{2}{*}{ High } & (HL) & 22 & 4.03 & 5.63 & 6.36 & 7.36 & 8.40 & 9.01 & 6.80 \\
\hline & LL-HL & & 0.02 & -0.41 & -0.19 & -.41 & -0.84 & -1.25 & -0.51 \\
\hline \multicolumn{10}{|c|}{$\begin{array}{l}\text { Type of } \\
\text { concentrate }\end{array}$} \\
\hline B & (B) & 21 & 3.89 & 5.28 & 6.15 & 6.98 & 7.70 & 8.21 & 6.37 \\
\hline \multirow[t]{2}{*}{ BRSM } & (BRSM) & 24 & 4.19 & 5.57 & 6.39 & 7.33 & 8.26 & 8.57 & 6.72 \\
\hline & B-BRSM & & -0.29 & -0.29 & -0.24 & -0.35 & -0.56 & -0.37 & -0.35 \\
\hline \multicolumn{9}{|c|}{ Standard error } & 0.17 \\
\hline \multicolumn{10}{|c|}{ Grass silage } \\
\hline \multicolumn{10}{|c|}{ Stage of cut } \\
\hline Early & (E) & 22 & 2.70 & 3.65 & 4.34 & 4.75 & 5.15 & 5.33 & 4.31 \\
\hline \multirow[t]{2}{*}{ Late } & (L) & 23 & 2.29 & 3.24 & 3.54 & 4.60 & 5.27 & 5.20 & 4.02 \\
\hline & E-L & & 0.41 & 0.41 & 0.80 & 0.15 & -0.12 & 0.13 & 0.29 \\
\hline \multicolumn{10}{|c|}{$\begin{array}{l}\text { Level of } \\
\text { concentrate }\end{array}$} \\
\hline Low & (LL) & 23 & 2.60 & 3.77 & 4.48 & 5.27 & 5.67 & 5.83 & 4.60 \\
\hline \multirow[t]{2}{*}{ High } & (HL) & 22 & 2.39 & 3.12 & 3.40 & 4.08 & 4.75 & 4.71 & 3.73 \\
\hline & LL-HL & & 0.21 & 0.65 & 1.08 & 1.19 & 0.92 & 1.11 & 0.87 \\
\hline \multicolumn{10}{|c|}{$\begin{array}{l}\text { Type of } \\
\text { concentrate }\end{array}$} \\
\hline B & (B) & 21 & 2.36 & 3.31 & 3.82 & 4.49 & 4.96 & 5.14 & 4.00 \\
\hline \multirow[t]{2}{*}{ BRSM } & (BRSM) & 24 & 2.63 & 3.59 & 4.06 & 4.86 & 5.47 & 5.39 & 4.33 \\
\hline & B-BRSM & & -0.28 & -0.28 & -0.25 & -0.37 & -0.51 & -0.25 & -0.33 \\
\hline \multicolumn{9}{|c|}{ Standard error } & 0.17 \\
\hline
\end{tabular}


Table 5. Total calculated amount of amino acids absorbed in the small intestine (AAT) and AAT of feed (AAT) and of microbial $\left(\mathrm{AAT}_{\mathrm{m}}\right.$ ) origin. Comparison of stage of maturity of grass for silage, level of concentrate and type of concentrate least squares means.

\begin{tabular}{|c|c|c|c|c|}
\hline & $\mathrm{n}$ & $\begin{array}{l}\mathrm{AAT} \\
\mathrm{g} \mathrm{d}^{-1}\end{array}$ & $\begin{array}{l}\operatorname{AAT}_{\mathrm{f}} \\
\mathrm{g} \mathrm{d}^{-1}\end{array}$ & $\begin{array}{l}\mathrm{AAT}_{\mathrm{m}}, \\
\mathrm{g} \mathrm{d}^{-1}\end{array}$ \\
\hline \multicolumn{5}{|l|}{ Stage of cut } \\
\hline Early (E) & 22 & 509 & 101 & 408 \\
\hline \multirow{2}{*}{$\begin{array}{ll}\text { Late } & \text { (L) } \\
& \text { E-L }\end{array}$} & 23 & 492 & 97 & 395 \\
\hline & & 17 & 3 & 14 \\
\hline \multicolumn{5}{|l|}{$\begin{array}{l}\text { Level of } \\
\text { concentrate }\end{array}$} \\
\hline Low (LL) & 23 & 456 & 81 & 376 \\
\hline \multirow{2}{*}{$\begin{aligned} \text { High , } & (\mathrm{HL}) \\
& \text { LL-HL }\end{aligned}$} & 22 & 545 & 117 & 427 \\
\hline & & -88 & -37 & -51 \\
\hline \multicolumn{5}{|l|}{$\begin{array}{l}\text { Type of } \\
\text { concentrate }\end{array}$} \\
\hline (B) & 21 & 475 & 76 & 399 \\
\hline \multirow{2}{*}{$\begin{aligned} \text { BRSM (BRSM) } & \text { B-BRSM }\end{aligned}$} & 24 & 526 & 122 & 404 \\
\hline & & -51 & -46 & -5 \\
\hline \multicolumn{2}{|l|}{ Standard error } & & & \\
\hline of differences & & 11 & 1 & 10 \\
\hline
\end{tabular}

feeding (Table 6) was due to the high PBV of the EC silage. Because of the negative PBV content of barley and the lower intake of grass silage, HL feeding resulted in a lower PBV than LL feeding. In addition to the increased AAT intake, inclusion of RSM in the diet increased the PBV, too. It should be noted that the calculated PBV on B feeding was positive, i.e., theoretically there seemed to be enough $\mathrm{N}$ for microbial protein synthesis in the rumen.

When the protein intake was expressed in terms of DCP, there was a large difference between EC and LC feeding (Table 7). This difference diminished in the course of the experiment $(\mathrm{p}<0.001$ for stage of cut ${ }^{*}$ period interaction), which reflects the changes in grass silage intake as well as the changes in chemical composition and digestibility of the silages. Compared to LL feeding, HL feeding resulted in a higher intake of DCP, the difference being larger towards the end of the experiment $\left(\mathrm{p}<0.001\right.$ for level of concentrate ${ }^{*}$ period interaction). Inclusion of RSM in the diet increased $(p<0.001$ for type of concentrate main effect) DCP intake, too, not only through the higher DCP content in RSM, but also through an increase in silage intake.

Due to the higher energy concentration and higher intake of the EC silage compared to the LC silage, the energy intake on EC feeding was higher than on LC feeding. However, the difference in energy intake between EC and LC feeding decreased $\left(\mathrm{p}<0.001\right.$ for stage of cut ${ }^{*}$ period interaction) during the experiment (Table 7). HL feeding also resulted in a higher energy intake. Due to differences in the pattern of concentrate supply, the difference in the energy intake between LL and HL feeding grew during the experiment $(\mathrm{p}<0.001$ for level of concentrate $*$ period interaction). Owing to the positive effect on voluntary grass silage intake, inclusion of RSM in the diet tended to increase the energy intake $(\mathrm{p}=0.12$ for type of concentrate main effect).

\section{LW gain}

The average live weights (LW) of the bulls during the course of the experiment are given in Table 8 . The corresponding LWGs are illustrated in Figure 2.

Compared to the LC bulls, the increased silage intake of the EC bulls resulted in only a slight increase in LWG. Calculated for the whole experimental period, the LWG for the EC and LC bulls was 1112 and $1099 \mathrm{~g} \mathrm{~d}^{-1}$, respectively (Table 8). The interaction between the effect of the stage of maturity of grass for silage and the period was significant $(\mathrm{p}=0.02)$. At the beginning of the experiment the EC bulls grew faster than the LC bulls, but the initially slower LWG of the LC bulls had been compensated by the end of the experiment (Figure 2a). As a result the feed conversion, calculated for the entire experimental period (Table 9), was impaired $(\mathrm{p}=0.01)$. Compared to LL feeding, a significant increase $(\mathrm{p}<0.005$ for level of concentrate main effect) in LWG was observed on HL feeding. 
Table 6. Protein intake $\left(\mathrm{g} \mathrm{d}^{-1}\right)$ during the production experiment in terms of AAT and PBV. Comparison of stage of maturity of grass for silage, level of concentrate and type of concentrate least squares means for each period and during the whole experiment.

Period

n

\section{AAT}

Stage of cut

Early

Late

(E)

(L)

E-L

$\begin{array}{rr}22 & 331 \\ 23 & 303 \\ & 29\end{array}$

403

34

Level of

\section{concentrate}

Low

High

( $\mathrm{HL}$

(HL)

LL-HL

$\begin{array}{rr}23 & 315 \\ 22 & 319 \\ & -5\end{array}$

$385 \quad 455$

$455 \quad 518$

505

534

543

456

$-69 \quad-62$

595

659

723

545

$-89$

$-125$

$-179$

$-88$

Type of concentrate

$\begin{array}{llllllllll}\text { B } & \text { (B) } & 21 & 292 & 396 & 465 & 525 & 565 & 606 & 475 \\ \text { BRSM } & \text { (BRSM) } & 24 & 342 & 444 & 508 & 575 & 628 & 660 & 526 \\ & \text { B-BRSM } & & -49 & -47 & -43 & -50 & -64 & -55 & -51\end{array}$

Standard error

of differences

$8 \quad 12$

PBV

Stage of cut

Early

(E)

22

120

166

179

173

249

238

188

Late

(L)

23

45

49

26

29

134

98

64

E-L

75

117

153

144

115

139

124

Level of

concentrate

$\begin{array}{llrrrrrrrr}\text { Low } & \text { (LL) } & 23 & 87 & 127 & 140 & 136 & 227 & 204 & 153 \\ \text { High } & \text { (HL) } & 22 & 78 & 88 & 66 & 67 & 156 & 132 & 98 \\ & \text { LL-HL } & & 9 & 39 & 75 & 69 & 71 & 72 & 56\end{array}$

Type of

concentrate

$\begin{array}{llrrrrrrrr}\text { B } & \text { (B) } & 21 & 54 & 75 & 67 & 64 & 151 & 136 & 91 \\ \text { BRSM } & \text { (BRSM) } & 24 & 111 & 140 & 138 & 139 & 232 & 199 & 160 \\ & \text { B-BRSM } & & -56 & -65 & -71 & -75 & -81 & -63 & -69\end{array}$

Standard error

of differences

4

$6 \quad 8$

8

9

8

6 
Table 7. Protein intake in terms of DCP $\left(\mathrm{g} \mathrm{d}^{-1}\right)$ and energy intake in feed units (FU) during the production experiment. Comparison of stage of maturity of grass for silage, level of concentrate and type of concentrate least squares means at each period and during the whole experiment.

\section{Period}

$\begin{array}{llllllll}\mathrm{n} & 1 & 2 & 3 & 4 & 5 & 6 & \text { Mean }\end{array}$

\section{DCP}

Stage of cut

Early (E)

Late

(E) $\quad 22 \quad 528$

(L) $\quad 23$

E-L

Level of

concentrate

$\begin{array}{llrrrrrrrr}\text { Low } & \text { (LL) } & 23 & 468 & 592 & 687 & 736 & 842 & 829 & 693 \\ \text { High } & \text { (HL) } & 22 & 466 & 639 & 696 & 782 & 931 & 979 & 749 \\ & \text { LL-HL } & & 2 & -46 & -9 & -45 & -88 & -150 & -56\end{array}$

Type of

concentrate

\begin{tabular}{|c|c|c|c|c|c|c|c|c|}
\hline \multirow{3}{*}{$\begin{array}{l}\text { B } \\
\text { BRSM }\end{array}$} & (B) & 21 & 409 & 555 & 632 & 693 & 809 & 840 \\
\hline & (BRSM) & 24 & 525 & 676 & 751 & 825 & 964 & 969 \\
\hline & B-BRSM & & -116 & -121 & -119 & -132 & -154 & -129 \\
\hline
\end{tabular}

Standard error

of differences

13

.20

24

24

25

23

18

FU

Stage of cut

Early (E)

Late

(E)

22

3.80

3.36

E-L

0.44

5.11

4.56

6.05

5.24

6.49

6.96

6.98

7.34

7.27

0.19

$-0.02$

0.07

5.96

$0.55 \quad 0.81$

0.19

4.48

5.35

5.95

6.32

6.37

8.23

5.34

Low

$\begin{array}{ll}(\mathrm{LL}) & 23 \\ (\mathrm{HL}) & 22\end{array}$

3.60

5.18

5.94

6.83

7.62

$-1.86$

6.23

LL-HL

$-0.04$

$-0.69$

$-0.59$

$-0.89$

$-1.30$

$-0.89$

Type of

concentrate

\begin{tabular}{|c|c|c|c|c|c|c|c|c|c|}
\hline B & (B) & 21 & 3.48 & 4.74 & 5.58 & 6.29 & 6.78 & 7.18 & 5.68 \\
\hline BRSM & (BRSM) & 24 & 3.67 & 4.92 & 5.71 & 6.50 & 7.16 & 7.43 & 5.90 \\
\hline & B-BRSM & & -0.18 & -0.18 & -0.13 & -0.21 & -0.38 & -0.25 & -0 . \\
\hline
\end{tabular}

Standard error

of differences

0.10

0.15

0.18

0.18

0.18

0.17

0.14 
Table 8. Live weight $(\mathrm{kg})$ during the course of the feeding experiment and live weight gain ( $\left.\mathrm{LWG}, \mathrm{g} \mathrm{d}^{-1}\right)$ calculated for the whole experimental period. Comparison of stage of maturity of grass for silage, level of concentrate and type of concentrate least squares means.

InitialAt the End of the Period

$\mathrm{n}$

$\begin{array}{lllllll}1 & 2 & 3 & 4 & 5 & 6 & \text { LWG }\end{array}$

\begin{tabular}{lrrrrrrrrrr}
\hline \multicolumn{2}{l}{ Stage of cut } & & & & & & & & & \\
Early & (E) & 22 & 124 & 184 & 260 & 326 & 387 & 445 & 497 & 1112 \\
Late & (L) & 23 & 121 & 178 & 245 & 305 & 375 & 434 & 490 & 1099 \\
& E-L & & 3 & 6 & 15 & 21 & 12 & 11 & 7 & 13
\end{tabular}

Level of concentrate

$\begin{array}{llrrrrrrrrr}\text { Low } & \text { (LL) } & 23 & 123 & 179 & 248 & 310 & 374 & 431 & 478 & 1058 \\ \text { High } & \text { (HL) } & 22 & 122 & 182 & 257 & 321 & 388 & 448 & 510 & 1153 \\ & \text { LL-HL } & & 1 & -3 & -9 & -11 & -14 & -17 & -32 & -95\end{array}$

Type of concentrate

\begin{tabular}{|c|c|c|c|c|c|c|c|c|c|c|}
\hline \multirow{3}{*}{$\begin{array}{l}\text { B } \\
\text { BRSM }\end{array}$} & (B) & 21 & 123 & 178 & 247 & 309 & 372 & 427 & 481 & 1066 \\
\hline & (BRSM) & 24 & 123 & 184 & 258 & 322 & 390 & 452 & 507 & 1145 \\
\hline & B-BRSM & & 0 & -6 & -11 & -13 & -18 & -24 & -26 & -79 \\
\hline $\begin{array}{l}\text { Standar } \\
\text { of differ }\end{array}$ & $\begin{array}{l}\text { error } \\
\text { ences }\end{array}$ & & 4 & 5 & 8 & 8 & 10 & 11 & 12 & 28 \\
\hline
\end{tabular}

Table 9. Carcass weight, dressing percentage, fat accretion and feed conversion. Comparison of stage of maturity of grass for silage, level of concentrate and type of concentrate least squares means.

\begin{tabular}{|c|c|c|c|c|c|c|}
\hline & & $\mathrm{n}$ & $\begin{array}{r}\text { Carcass } \\
\text { weight } \\
(\mathrm{CW}), \mathrm{kg}\end{array}$ & $\begin{array}{r}\text { Dressing, } \\
\% \\
\% \text { of } \mathrm{CW}\end{array}$ & $\begin{array}{r}\text { Fat in } \\
\text { abdominal } \\
\text { cavity, }\end{array}$ & $\begin{array}{r}\text { Feed } \\
\text { conversion } \\
\text { FU/kg LWG }\end{array}$ \\
\hline \multicolumn{7}{|c|}{ Stage of cut } \\
\hline Early & (E) & 22 & 265 & 53.3 & 9.38 & 5.37 \\
\hline Late & (L) & 23 & 261 & 53.4 & 8.02 & 5.12 \\
\hline & E-L & & 4 & -0.1 & 1.36 & 0.25 \\
\hline \multicolumn{7}{|c|}{$\begin{array}{l}\text { Level of } \\
\text { concentrate }\end{array}$} \\
\hline Low & (LL) & 23 & 252 & 53.0 & 7.99 & 5.06 \\
\hline High & (HL) & 22 & 274 & 53.8 & 9.41 & 5.43 \\
\hline & LL-HL & & -22 & -0.8 & -1.42 & -0.37 \\
\hline \multicolumn{7}{|c|}{$\begin{array}{l}\text { Type of } \\
\text { concentrate }\end{array}$} \\
\hline B & (B) & 21 & 257 & 53.5 & 8.47 & 5.34 \\
\hline BRSM & (BRSM) & 24 & 269 & 53.2 & 8.93 & 5.15 \\
\hline & B-BRSM & & -12 & 0.3 & -0.46 & 0.19 \\
\hline $\begin{array}{l}\text { Standard } \\
\text { error of } \\
\text { difference }\end{array}$ & & & 6 & 0.3 & 0.54 & 0.09 \\
\hline
\end{tabular}

1) FU, fattening feed unit; LWG, live weight gain. 
a

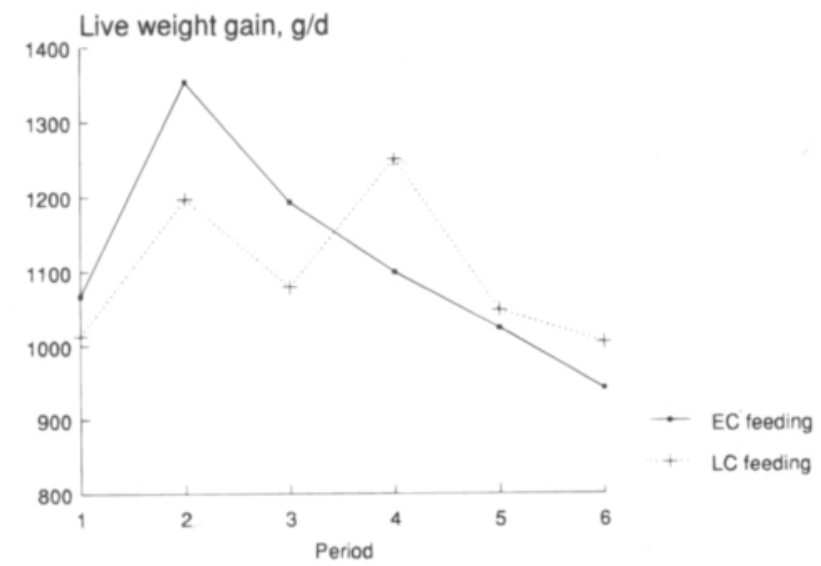

b

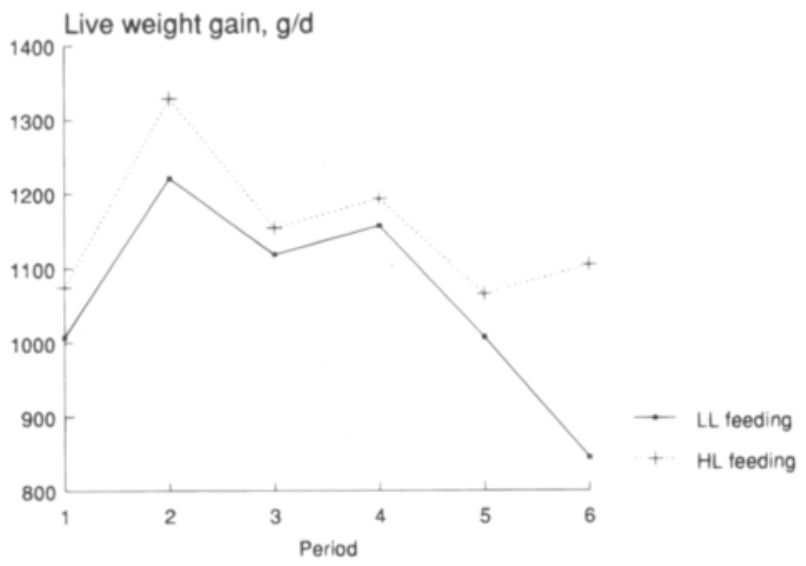

C

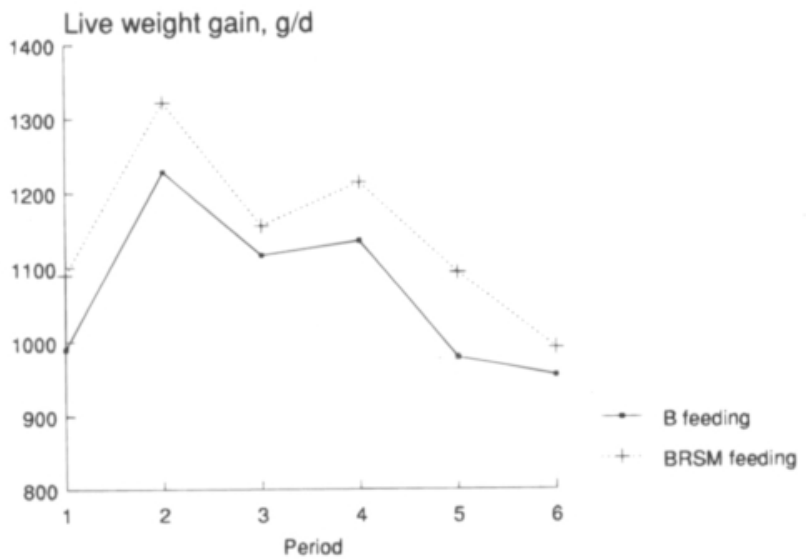

Fig. 2. Mean profiles illustrating the effects of stage of maturity of grass for silage (a) and level (b) and type (c) of concentrates on the rate of daily live weight gain. EC, early-cut silage; LC, late-cut silage; LL, low level of concentrates; HL, high level of concentrates; B, barley; BRSM, barley and rapeseed meal. 
On an average, the LWG on LL feeding was $1058 \mathrm{~g}$ $\mathrm{d}^{-1}$ and on $\mathrm{HL}$ feeding $1153 \mathrm{~g} \mathrm{~d}^{-1}$. However, the feed conversion of the HL bulls was impaired $(\mathrm{p}<0.001)$. The BRSM bulls had a higher $(\mathrm{p}=0.01)$ LWG than B bulls. The positive effect of RSM inclusion in the diet on LWG was sustained throughout the experiment (Figure 2c). The LWG of the B and BRSM bulls was on an average 1066 and 1145 $\mathrm{g} \mathrm{d}^{-1}$, respectively. RSM affected feed conversion positively $(\mathrm{p}=0.04)$.

\section{Diet digestibility}

The grass silages fed during the in vivo digestibility trial (Period 6) were of second cut, and the difference in chemical composition between the two stages of maturity was small (Table 2). However, the E silage was more fermented than the L silage (Table 1).

In the multivariate analysis of variance for diet digestibility, no interactions were detected between the treatments. For brevity, only the results of the main effects along with the corresponding results
Table 10. Results of the diet digestibility data subjected to univariate and multivariate analyses of variance.

\begin{tabular}{|c|c|c|c|c|}
\hline \multirow{3}{*}{$\begin{array}{l}\text { Source } \\
\text { Stage of cut }\end{array}$} & \multicolumn{2}{|c|}{ Univariate } & \multicolumn{2}{|c|}{ Multivariate } \\
\hline & $\begin{array}{l}\text { F-value } \\
\text { (df } 1,31)\end{array}$ & $\mathrm{p}$ & $\begin{array}{l}F_{0} \text {-value } \\
\text { (df 4,28) }\end{array}$ & ) $p$ \\
\hline & & & 2.64 & 0.06 \\
\hline $\mathrm{CP}^{2)}$ & 0.12 & 0.74 & & \\
\hline $\mathrm{EE}^{2)}$ & 0.54 & 0.47 & & \\
\hline $\mathrm{CF}^{2)}$ & 0.58 & 0.45 & & \\
\hline $\mathrm{NFE}^{2)}$ & 6.72 & 0.01 & & \\
\hline Level of concentrate & & & 29.20 & $<0.001$ \\
\hline $\mathrm{CP}$ & 9.82 & $<0.001$ & & \\
\hline $\mathrm{EE}$ & 9.06 & 0.01 & & \\
\hline CF & 45.30 & $<0.001$ & & \\
\hline NFE & 20.80 & $<0.001$ & & \\
\hline
\end{tabular}

\begin{tabular}{|c|c|c|}
\hline \multicolumn{3}{|c|}{ Type of concentrate } \\
\hline CP & 12.60 & $<0.001$ \\
\hline EE & 14.48 & $<0.001$ \\
\hline CF & 2.45 & 0.13 \\
\hline NFE & 0.20 & 0.66 \\
\hline
\end{tabular}

1) $\mathrm{F}_{0}$-test statistic is based on Wilk's Lambda.

2) $\mathrm{CP}$, crude protein $(\mathrm{MSE}=6.19)$; $\mathrm{EE}$, ether extract (MSE=5.15);

$\mathrm{CF}$, crude fibre $(\mathrm{MSE}=6.76)$; NFE, nitrogen-free extracts (MSE=2.24).

Table 11. Diet digestibility (\%). Comparison of stage of maturity of grass for silage, level of concentrate and type of concent -rate least squares means.

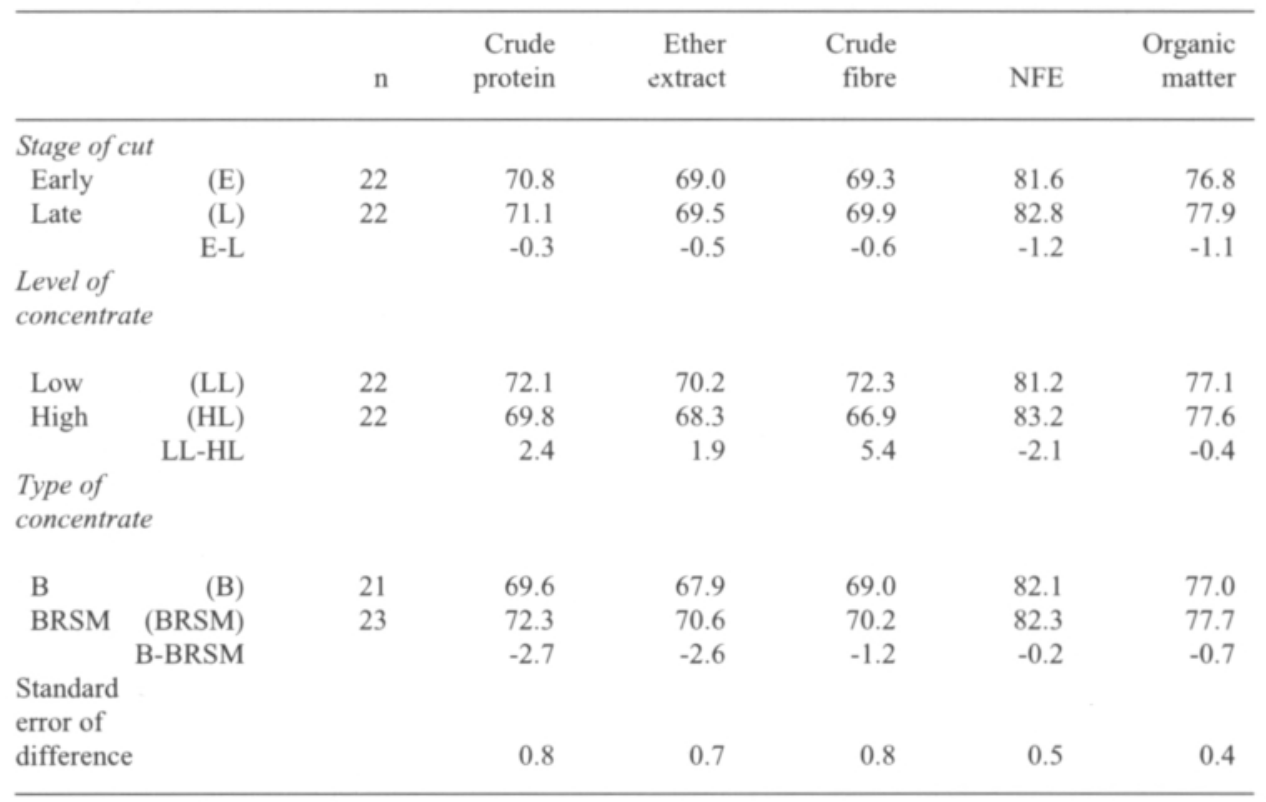

${ }^{1)} \mathrm{FU}$, fattening feed unit; LWG, live weight gain. 
of the univariate analyses are shown in Table 10. In Table 11, the least squares means of the main effects are given. The estimated contrasts in the main effects with their standard errors are also included in the table, as well as the corresponding estimates for the organic matter.

The digestibility of the LC diet tended to be higher than that of the EC diet. As indicated by the univariate analyses, this difference seemed to originate from the digestibility of nitrogen-free extracts (Table 10). Except for nitrogen-free extracts, the increased concentrate supply had a negative effect on diet digestibility.

Inclusion of RSM in the diet had a positive effect on diet digestibility (Tables 10 and 11). Inspection of the univariate tests showed that this was mainly due to the digestibility of crude protein and ether extracts. Furthermore, the univariate test showed some evidence of a difference in crude fibre digestibility between the B and BRSM diets.

\section{Discussion}

\section{Chemical composition and feed value of the feeds}

The rate of change in the chemical composition of the grasses in relation to the time interval between the harvesting of the EC and LC silages was found to be slow. CP content decreased by $0.39 \%$-units and CF content increased by $0.35 \%$-units per day for the silages of the first cut. For the second-cut silages the rate of change was even slower. These values are lower than those reported by POUTIAINEN and RINNE (1971) and SYRJÄLÄ and OJALA (1978). In their experiments, the decrease in $\mathrm{CP}$ content was 0.62 and $0.45 \%$-units per day and the increase in CF content 0.40 and $0.64 \%$-units per day, respectively. The grass species used as well as the weather conditions may at least partly explain these differences.

The digestibility of early-cut grass silage is usually higher than that of late-cut grass silage (Poutiainen and RinNe 1971, SyrJÄLÄ and OJala 1978, STEEN 1984), but the effect of the date of cut is smaller in second-cut than in first-cut silage (SYRJÄLÄ et al. 1978). This was also the case in the present experiment. The digestibility of OM decreased by $0.49 \%$-units per day with the first-cut silages and only by $0.2 \%$-units per day with the second cut silages (measured in wethers, data not presented).

DEG of the silages was calculated using the rumen outflow rate $(=\mathrm{k})$ of $3 \% \mathrm{~h}^{-1}$. This was considered to be justified, because particle passage rates of this order have frequently been reported for roughages (e.g., TAMMINGA 1989, KUKKONEN and HUHTANEN 1991, JAAKKOLA et al. 1991). If a kvalue of $8 \% \mathrm{~h}^{-1}$ had been used, the average AAT value obtained for the EC silage would have been $66.3 \mathrm{~g} \mathrm{~kg}^{-1} \mathrm{DM}$ and for the LC silage 62.9.

If the higher k-value is used, a larger proportion of the calculated AAT would be of feed origin, and, thus, the AAT value of the feed would be more susceptible to the digestibility of the rumen undegradable protein. In this experiment, digestibilities of 39 and $25 \%$ were calculated for the rumen undegradable protein of the EC and LC silages, and 83 and $81 \%$ for barley and mixture of barley and rapeseed meal. The relatively low digestibilities in the silages may be explained by the fact that the non-degradable roughage protein is mostly bound with the cell wall which is not digested in the small intestine and only to a negligible extent in the large intestine (ZEBROWSKA and KowALCZYK 1991).

\section{Diet digestibility and feed intake}

The higher digestibility of the LC diet compared to the EC diet had not been expected. The fact that the silages fed during the digestibility trial with growing bulls were of the second cut may have contributed to this unexpected result. However, during the earlier phase of the growth trial the difference between the two silages as to the stage of cut and, hence, as to chemical composition and digestibility was larger (OM digestibility, measured in wethers, of $78.4 \%$ for the EC and $74.2 \%$ for the LC silage). Due to better digestibility the bulls on EC feeding tended to consume more grass silage than those on 
LC feeding. This is in agreement with the results reported by STEEN (1984) and MARTINSSON (1990). The difference in grass silage intake between the animals receiving silages cut at different stages of maturity decreased during the experiment, which was obviously related to the changes in digestibility and fermentation quality of the two grass silages. Silage fermentation products have been shown to be important in controlling voluntary intake (ThiAGO and Gill 1986, HeIKKILÄ et al. 1989).

Inclusion of RSM in the diet was found to increase the grass silage intake, which is in agreement with earlier studies (ARONEN 1991, ARONEN and Vanhatalo 1992). It should be noticed that the positive effect of RSM was apparent throughout the experiment and did not depend on stage of maturity of grass for silage or on the level of concentrates.

The increased silage intake caused by the inclusion of RSM in the diet is consistent with the slightly improved diet digestibility. Similarly, GILL and ENGLAND (1984) observed both an enhanced diet digestibility and increased grass silage intake when protein supplements were included in the diet. These findings are in accordance with the suggestion that the increase in feed intake, caused by protein supplements, is mediated by improved microbial activity and the thereby increased diet digestibility (NOCEK and RUSSELL 1988). Nevertheless, with growing heifers, inclusion of RSM or meat and bone meal in a diet based on grass silage and barley did not have any significant effect on rumen digestibility of the diet NDF and ADF or on rumen microbial protein production (ARONEN and VANHATALO 1992). In that experiment, however, the feeding level was lower $\left(70 \mathrm{~g} \mathrm{DM} \mathrm{kg}^{-1} \mathrm{~W}^{0.75}\right)$ than in the present experiment, which may have contributed to the results.

As expected, an increased concentrate supply had a negative effect on crude fibre digestibility. HuHTANEN and JAAKKOLA (1992) obtained similar results when the proportion of concentrates in the diet exceeded $50 \%$. In the present experiment, the proportion of concentrates in total DM intake was 29 and $49 \%$ on an average for LL and HL feeding, respectively. Similarly, in an experiment by THO-
MAS et al. (1988) an increase in the proportion of barley in a grass silage-based diet was accompanied by marked reductions in the digestibility of NDF and ADF.

The LL bulls had a higher silage intake than the HL bulls. The substitution rate, calculated for the whole experimental period, was $0.63 \mathrm{~kg}$ silage DM per kg of concentrate DM regardless of the stage of cut. This figure is close to the values reported by STEEN (1984) for early-cut and late-cut silages ( 0.65 and $0.61 \mathrm{~kg}$, respectively). MARTINSSON (1990) reported that per kg of concentrate DM fed, the depression in silage DM intake was greater with an early-cut $(0.76 \mathrm{~kg})$ silage than with a late-cut one $(0.64 \mathrm{~kg})$. In his experiment, however, the time interval between the two stages of cut was longer (20 days) than in the present experiment, and hence, the difference in digestibility of organic matter was larger.

\section{Animal performance}

At the beginning of the experiment the bulls on EC feeding grew faster than the bulls on LC feeding. As a consequence of the diminishing difference in grass silage intake between the EC and LC bulls during the course of the experiment, the initially slower LWG of the LC bulls had been compensated by the end of the experiment. Similarly, BERGE et al. (1991) reported compensatory growth in Friesian bulls during the fattening period after growth limitation during the growing period.

In other experiments concerning the stage of maturity of grass at harvesting (STEEN 1984, THOMAS et al. 1988, MARTINSSON 1990), the difference in LWG between the animals receiving early- and late-cut silages has been larger than in the present experiment. However, the time interval between the cuts has been larger and, hence, the difference in the chemical composition and digestibility of the silages has also been larger. In the present experiment the time interval between the two cuts was eight days on an average.

The increased LWG on HL feeding compared to LL feeding was followed by an impaired feed con- 
version. This could be explained, at least partly, by an increased proportion of fat in the abdominal cavity (Table 9). Analogously, the anatomical cut of the carcasses revealed that the relative proportion of intermuscular and subcutaneous fat, as percentage of the half carcass, was higher with the HL bulls than with the LL bulls (ARONEN et al. 1992). According to GEAY and Micol (1989), the higher the LWG and energy intake, the more rapidly fat is deposited.

Consistent with earlier findings (ARONEN 1991, ARONEN and VANHATALO 1992), the BRSM bulls gained weigt faster than the $\mathrm{B}$ bulls. The positive effect of RSM on LWG could be explained by the increased feed intake and the thereby higher energy intake. However, as proposed by THOMAS and GILL (1987), the positive effect of protein feeds on LWG can be interpreted both ruminally in terms of the influence of the degradable fraction of feed protein on microbial synthesis, and metabolically in relation to the effects of the undegraded fraction in increasing the supply of amino acids to the tissues. Thus, the possibility that the improved animal performance was caused by the increased amount or improved balance of amino acids flowing to the intestines cannot be excluded, either. Indeed, the calculated supply of AAT was greater on BRSM feeding than on B feeding.

In agreement with earlier findings reported by HAKKOLA (1985), JoKI-TOKOLA (1991) and ARONEN and VANHATALO (1992), the positive effect of RSM on LWG was sustained throughout the experiment, unlike in some other experiments (HuHTANEN et al. 1989, ARONEN 1990), in which the positive effect of RSM on LWG was restricted to the early phase of the growth period (i.e., LW below $300 \mathrm{~kg}$ ). The reason for this discrepancy remains unclear, but it may be related to differences in the quality and chemical composition of grass silages between the experiments and also within the experiments. E.g., in the experiment by ARONEN (1990), the CP content of the grass silage was high throughout the experiment, whereas in the experiment reported by ARONEN and VANHATAlo (1992), the CP content of the silages decreased towards the end of the experiment.

In accordance with WATERHOUSE et al. (1983), the response in LWG to the inclusion of RSM in the diet seemed to be smaller with the high concentrate level $(52 \mathrm{~g} / \mathrm{d})$ than with the low concentrate level $(105 \mathrm{~g} / \mathrm{d})$. However, this interaction was not statistically significant $(\mathrm{p}=0.36)$.

The absence of interaction in LWG (and also in diet digestion and silage intake) between protein supplementation and the stage of maturity of grass for silage may be explained by the relatively small difference in chemical composition and digestibility between the two silages. On the other hand, this finding suggests that the grass silage protein in excess of $125-135 \mathrm{~g} \mathrm{~kg}^{-1}$ DM may be useless for rumen microbes and may be lost in the urine. The high positive $\mathrm{PBV}$ values for the EC diet may indicate this.

It should be noted that, in terms of DCP, the protein supply on B feeding with the EC silage during the entire experimental period and with the LC silage during Periods 3 to 6 was more than adequate, according to the Finnish protein feeding standards (SALO et al. 1990). It is, therefore, possible that those standards are too low, or, which is more likely, that the animals were not able to take full advantage of the highly soluble and degradable silage protein. Indeed, JAAKKOLA and HUHTANEN (1992) observed an inefficient utilization of $\mathrm{N}$ in early-cut silages for microbial protein synthesis in the rumen.

In conclusion, the animals in this experiment were unable to completely utilize the high protein content of the EC silage. Nevertheless, the inclusion of RSM in the diet, which contained enough protein in terms of DCP, improved LWG and resulted in more efficient feed conversion. The positive effects of RSM were obviously mediated by the improved diet digestibility and the thereby increased grass silage intake. On the other hand, the possibility that the enhanced animal performance was caused by an increased amount or improved balance of amino acids flowing to the intestines could not be excluded. It is suggested, therefore, that the quantity and amino acid composition of 
non-ammonia nitrogen flowing to the intestines, as a response to RSM supplementation be determined in future studies.

Diets based on grass silage with a high protein content are characterized by their high PBV content. It appears that increasing the concentrate level (barley or other feeds with a negative PBV value) will decrease the high PBV value of the silage diet and thereby reduce $\mathrm{N}$ losses.

Acknowledgements. The authors are grateful to Ms. Tuija Olenius and Mr. Kalle Saastamoinen and his staff for their skilful technical assistance during the experiment. The rapeseed meal used for this experiment was received from Öljynpuristamo Ltd., which is gratefully acknowledged.

\section{References}

Aronen, I. 1990. Barley Protein and Rapeseed Meal as Protein Supplements for Growing Cattle. Acta Agric. Scand. 40: 297-307.

- 1991. Influence of frequency and accuracy of supplement feeding on rumen fermentation, feed intake, diet digestion and performance of growing cattle 1. Studies with growing bulls fed grass silage ad libitum. Anim. Feed Sci. Technol. 34: 49-65.

— \& Vanhatalo, A. 1992. Heat-Moisture Treatment of Rapeseed Meal: Effect on Digestibility of the Diet, Voluntary Grass Silage Intake and Growth Rate of Ayrshire Bulls. Acta Agric. Scand., Sect. A, Animal Sci. 42: 157-166.

-, Toivonen, V., Röpelinen, A. \& Ketoja, E. 1992. The effect of date of cut of grass silage and type and amount of supplementary concentrates on carcass and meat quality of Ayrshire bulls. Proc. of the 14th General Meeting of the European Grassland Federation Lahti, Finland. p. 564-566.

Berge, P., GeAY, Y. \& MiCOL, D. 1991. Effect of feeds and growth rate during the growing phase on subsequent performance during the fattening period and carcass composition in young dairy breed bulls. Livest. Prod. Sci. 28:203-222.

Cody, R.F., Murphy, J.J. \& Morgan, D.J. 1990. Effect of supplementary crude protein level and degradability in grass silage-based diets on performance of dairy cows, and digestibility and abomasal nitrogen flow in sheep. Anim. Prod. 51: 235-244.

Crowder, M.J. \& HAND, D.J. 1990. Analysis of repeated measures. Chapman \& Hall, London. p. 279.

Donaldson, R.S., McCann, M.A., Amos, H.E. \& HoveLAND, C.S. 1991. Protein and fiber digestion by steers grazing winter annuals and supplemented with ruminal escape protein. J. Anim. Sci. 69: 3067-3071.

ETTALA, E. \& LAMPILA, M. 1978. Factors affecting voluntary silage intake by dairy cows. Ann. Agric. Fenn. 17: 163-174.
GEAY, Y. \& MiCOL, D., 1989. Growing and finishing cattle. In: Jarrige, R. (ed.). Ruminant Nutrition. Recommended Allowances \& Feed Tables, p. 121-151. John Libbey and Co Ltd, England.

Gill, M. \& EnGLAND, P. 1984. Effect of degradability of protein supplements on voluntary intake and nitrogen retention in young cattle fed grass silage. Anim. Prod. 39: 31-36.

HAKKOLA, H.S. 1985. Barley and protected protein concentrate as supplements to timothy silage for growing bulls. The International Grassland Congress, XV. Kyoto, Japan.

HEIKKILÃ, T., VÄÄTÄINEN, H. \& LAMPILA, M. 1989. Effect of silage quality on milk yield and composition in dairy cows. Int. Symp. on production, evaluation and feeding of silage. Rostock, GDR. 4 p.

Huhtanen, P., Poutiainen, E. \& Mikkola, T. 1985. The effect of supplementation of grass silage with rapeseed meal or Gasol-treated barley on the performance of growing cattle. J. Agric. Sci. Finl. 57: 75-84.

—, NÄSI, M. \& KHALILI, H. 1989. By-products from integrated starch-ethanol production from barley in the diets of growing cattle. J. Agric. Sci. Finl. 61: 451-462.

- \& JAAKKOLA, S. 1992. The effects of the forage preservation method and the proportion of concentrate on digestion of cell wall carbohydrates and rumen digesta pool size in cattle. Grass and Forage Science. In press.

HuIDA, L., VÄÄTÄInen, H. \& LAMPILA, M. 1986. Comparison of dry matter contents in grass silages as determined by oven drying and gas chromatographic water analysis. Ann. Agric. Fenn. 25: 215-230.

Hvelplund, T., WeisbJerg, M.R. \& Andersen, L.S. 1991. Estimation of the True Digestibility of Rumen Undegraded Dietary Protein in the Small Intestine of Ruminants by the Mobile Bag Technique. Acta Agric. Scand., Sect. A, Animal Sci. 42: 34-39.

JaAkKola, S., Huhtanen, P. \& Hissa, K. 1991. The effect of cell wall degrading enzymes or formic acid on fer- 
mentation quality and on digestion of grass silage by cattle. Grass and Forage Science 46: 75-87.

— \& HuhtANEN, P. 1992. The effect of grass maturity on nitrogen metabolism in the rumen of cattle receiving silage-based diet. Proc. of the 14th General Meeting of the European Grassland Federation, Lahti, Finland. p. 588-590.

JOKI-TOKOLA, E. 1991. Lihaluurehujauho ja rypsirouhe sonnien valkuaisrehuna. Koetoimin. ja Käyt. 48: 64.

KukKonen, U. \& Huhtanen, P. 1991. Rate of passage calculations based on marker or rumen evacuation technique. Anim. Prod. (Abstr.) 52, 3:592-593.

MAFF 1975. Energy allowances and feeding systems for ruminants. Ministry of Agriculture, Fisheries and Food, Tech. Bull. 33, HMSO, London, p. 79.

Martinsson, K. 1990. The Effects of Forage Digestibility and Concentrate Supplementation on Performance of Finishing Bulls. Swedish J. Agric. Res. 20: 161-167.

Michalet-Doreau, B. \& Ould-Bah, M.Y. 1989. Estimation of the extent of bacterial contamination in bag residues and its influence on in sacco measurements of forage nitrogen degradation in rumen. XVI Int. Grassl. Congr. Nice, France. p. 909-910.

MoloneY, A.P. 1991. Growth, digestibility and nitrogen retention in young friesian steers offered grass silage and concentrates which differed in protein concentration and degradability. 6th Int. Symp. Prot. Metab. and Nutr. Herning, Denmark. p. 342-344.

NOCEK, J.E. \& RuSSELL, J.B. 1988. Protein and Energy as an Integrated System. Relationship of Ruminal Protein and Carbohydrate Availability to Microbial Synthesis and Milk Production. J. Dairy Sci. 71: 2070-2106.

ØrSKov, E.R. \& MCDONALD, I. 1979. The estimation of protein degradability in the rumen from incubation measurements weighted according to rate of passage. J. Agric. Sci. Camb. 92: 499-503.

Pearce, S.C. 1983. The Agricultural Field Experiment. A Statistical Examination of Theory and Practice. John Wiley \& Sons Ltd. 335 p. Chichester.

Poutiainen, E. \& RinNE, K. 1971. Korjuuasteen vaikutus säilörehun ravintoarvoon. Kehittyvă maatalous 3: 15-28.

SALO, M.-L., TUORI, M. \& KIISKINEN, T. 1990. Rehutaulukot ja ruokintanormit. Helsinki. $70 \mathrm{p}$.

SAS 1990. SAS/STAT User's Guide, Version 6, 4th Edition, Volume 2. Cary, NC, USA.

STEEN, R.W.J. 1984. A comparison of two-cut and three-cut systems of silage making for beef cattle using two cultivars of perennial ryegrass. Anim. Prod. 38: 171-179.

- 1988. The effect of supplementing silage-based diets with soya bean and fish meals for finishing beef cattle. Anim. Prod. 46: 43-51.

SYRJÄLĀ, L. \& OJALA, R. 1978. Kevăt- ja syyssadosta eri kehitysasteilla valmistetun timoteisăilörehun ravintoarvo. Kehittyvă Maatalous 39: 36-49.

-, Suvitie, M. \& Seppälä, J. 1978. Timoteinurmen sato, koostumus ja sulavuus kasvukauden eri aikoina. Kehit- tyvä Maatalous 39: 27-35.

Tamminga, S., Robinson, P.H., Vogt, M. \& BoeR, H. 1989. Rumen Ingesta Kinetics of Cell Wall Components in Dairy Cows. Anim. Feed Sci. Technol. 25: 89-98.

Thiago, R.S. \& GiLl, M. 1986. The effect of conservation method and frequency of feeding on the removal of digesta from the rumen. Proc. Nutr. Soc. 45, 97 A.

Thomas, C. \& Gill, M. 1987. Principles of Silage Utilization and Supplementation. Efficient Beef Production from Grass. Occasional Symposium No. 22, British Grassland Society.

-, GibBs, B.G., BeEver, D.E. \& Thurnam, B.R. 1988. The effect of date of cut and barley substitution on gain and on the efficiency of utilization of grass silage by growing cattle. Br. J. Nutr. 60: 297-306.

Tulisalo, U. 1990. Mitä on Öpex-rouhe? Kotielăin 3: 14.

Vanhatalo, A., Varvikko, T. \& Aronen, I. 1992. The effect of type of additive on rumen fermentation and digestion of grass silage in cattle. Agric. Sci. Finl. 1: 163-175.

Van Keulen, J. \& Young, B.A. 1977. Evaluation of acidinsoluble ash as a natural marker in ruminant digestibility studies. J. Anim. Sci. 44: 282-287.

Waterhouse, A., Laird, R. \& Holliday, R.J. 1983. A response to protein supplementation of grass silage for growing and finishing cattle. Anim. Prod. 36: 503 (Abstr.).

Weisbjerg, M.R., Bhargava, P.K., Hvelplund, T. \& MaDSEN, J. 1990. Anvendelse af nedbrydningsprofiler i fodermiddelvurderingen. Beretn. 679 fra Statens Husdyrbrugsforsog.

ZebrowsKa, T. \& KowalczyK, J. 1991. Protein digestion in ruminants: influence of carbohydrates and fat. 6th Int. Symp. Prot. Metab. and Nutrit. Herning, Denmark. p. 54-65.

\section{Manuscript received March 1992}

\section{Ilmo Aronen}

Vesa Toivonen

Agricultural Research Centre of Finland

Institute of Animal Production

SF-31600 Jokioinen, Finland

\section{Elise Ketoja}

Jukka Öfversten

Agricultural Research Centre of Finland

Data and Information Services

SF-31600 Jokioinen, Finland 


\title{
SELOSTUS
}

\section{Säilörehun korjuuaste ja väkirehutäydennyksen määrä ja laatu lihanautojen ruokinnassa}

\author{
Ilmo Aronen, Vesa Toivonen, Elise Ketoja ja JukKa ÖfVersten \\ Maatalouden tutkimuskeskus
}

Tutkimuksessa selvitettiin, miten säilörehun korjuuaste (aikaisin $(=\mathrm{EC})$ tai 8 päivää myöhemmin $(=\mathrm{LC})$ korjattu koiranheinä-timoteisäilörehu), väkirehutäydennyksen määrä (matala (=LL, $1.5 \mathrm{~kg}$ kuiva-ainetta $(\mathrm{ka}) / \mathrm{pv})$ tai korkea $(=\mathrm{HL}$, $3.0 \mathrm{~kg} \mathrm{ka} / \mathrm{pv})$ ) ja laatu (văkirehuna ohra $(=\mathrm{B})$ tai ohran ja rypsirouheen seos $(=$ BRSM)) vaikuttavat rehuannoksen sulavuuteen sekă ay-sonnien säilörehun syöntiin ja kasvunopeuteen. Tutkimuksessa käytettiin satunnaistettujen lohkojen koekaaviota ja $2^{3}$ faktoriaalisia koetekijöitä.

Vapaasti syötettyjen EC ja LC säilörehujen raakavalkuaispitoisuudet olivat keskimäärin 15.9 ja $13.1 \%$. Vastaavat raakakuitupitoisuudet olivat 27.8 ja $30.4 \%$.

Tutkimuksen alussa EC sonnit söivăt enemmăn săilörehua kuin LC sonnit. Ero kuitenkin pieneni kokeen edetest. Eläinten kasvu seurasi săilörehun syőntiă siten, että kasvatuskauden alun LC sonnien hitaampi kasvunopeus kompensoitui kokeen edetessä.

HL sonnit söivät văhemmän säilörehua kuin LL sonnit. Kasvuasteesta riippumatta săilörehun kuiva-aineen syönti văheni keskimäärin 0.63 kg lisăttyă văkirehun kuiva-ainekiloa kohti.

Aikaisin korjattua săilörehua ja ohraa syötettåesså rehuannoksen laskennallinen valkuaisväkevyys suomalaisten normien mukaan oli riittävä. Kuitenkin rypsirouheen sisällyttäminen rehuannokseen ( $500 \mathrm{~g}$ koko kasvatuskauden ajan) lisăsi eläinten săilörehun syöntiă kasvuasteesta riippumatta' Myös sonnien kasvu nopeutui merkitsevăsti ja rehun hyväksikäyttő oli tehokkaampaa BRSM ruokinnalla B ruokintaan verrattuna. Näin ollen on ilmeistä, ettă sonnit eivăt pystyneet kăyttămăăn hyvăkseen kaikkea aikaisin korjatun säilörehun typpeä.

Rypsirouheen säilörehun syöntiä lisäävă vaikutus viittaa siihen, että nimenomaan pötsimikrobit hyötyivăt rypsirouheen valkuaisesta. Tătă päătelmäă tukee tutkimuksessa havaittu rypsirouheen rehuannoksen sulavuutta lisăăvă vaikutus. On myös mahdollista, että rypsirouheen pötsissä hajoamaton ohitusvalkuainen vaikutti myönteisesti eläinten kasvuun. 